\title{
THE CONCEPT AND THE SPACE DESIGN OF BAJAU LAUT TRADITIONAL HOUSE
}

\author{
Zaimie Sahibil \\ Univeriti Malaysia Sabah \\ (dasarlaut70@yahoo.com.my) \\ DOI: https://doi.org/10.22452/brj.sp2019no1.4
}

\begin{abstract}
The Sea Bajau(s) is one of the earliest known communities inhabiting the coastal areas and islands of Sabah. They practice the traditional way of life and live in various traditional houses that are unique to their community. Samal is the language spoken by the Sea Bajau(s) who are mainly fishermen and whose source of living comes from the sea. This research explores the concept and use of space in Sea Bajau traditional houses in the coastal areas and islands of Sabah, in particular, the villages around Kudat and Semporna. The focus is on the concept, creative composition in relations to the process of building a traditional Sea Bajau(s) house in detail. The process in building a traditional house is tightly woven into the customs, cultural practices and religion of the Sea Bajau(s). The ceremonies or rituals involved in the process reaffirm the belief that it functions as a guide to goodness and well-being. The Sea Bajau house concept is unique and different from other traditional houses in Sabah because of its evolvement from different stages. From houseboats to houses above the water and then a house on the land, the Sea Bajau(s) houses have evolved through three stages that will also be documented in this paper.
\end{abstract}

Keywords: Samal language, concept, creative composition, the customs, cultural practices, religion, rituals, house concept, traditional house and the Sea Bajau.

\section{Introduction}

The Bajau Laut community is the largest populated tribe living in the archipelago and the coast of Sabah. The boats are their traditional house which has many different types and shapes that have been used since dying. Living in 'no state' societies enables them to explore from one area of water to another freely. They live in canopy boats or boards. The Bajau Laut people live nomadic because the absence of a particular area is a permanent residence. Only boats are used as a place for the occupants of the family. In a narrow space to sleep, the entire Bajau Laut family was able to survive in the boat. They are not free to set foot on the ground as boats are full of nets and barrels to store rock and fish. They never complain, let alone be upset with such a way of life. The history of the origins of the arrival of the Bajau Laut of Sabah exists in two forms. The first results from the study and research of western writers. Second, through legendary 
stories in Bajau Laut society about their origins. Several theories explain the arrival of Bajau people to Sabah. Firstly, some say that the Bajau people are from Johor (Sopher, 1965, pp. 141-142).

In times of circulation, the Bajau Laut community began to make permanent houses on the surface of the water around the island and the coast. Then this community began to make a home on land due to safety and geographical factors. The construction of the Bajau Laut community's traditional home over water and land only takes a short time, within a week. Small built-in homes and simple, easy-to-build designs and without any special plans. The Bajau Laut community also takes into account several factors in the construction of their homes as shelters, security and places for raising children. The number of households living in a house is also usually a family, which is between two and three families.

The cause of displacement from houseboat to home over water and land is due to the fragile houseboat. In addition, Bajau Laut people have evolved through mixed marriages between the Bajau Sea and other communities on the continent.

\section{Bajau Laut Traditional House}

The Bajau Laut houses of this tradition still exist and can be seen in several coastal areas and the islands of Sabah, especially in the villages. The division of space design takes into account the function, size and design of the filling. The concepts and designs highlighted in this study are comprehensive and detailed studies related to the various aspects of their production. In terms of space and part of the house, materials, equipment, processes, design influences that may be associated with the environment, climate, way of life, values and beliefs of Bajau Laut. Its formation takes into account the background of the tribe, the environment, the culture and the beliefs, the need for protection and security.

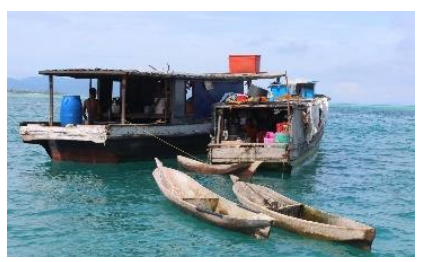

(i)

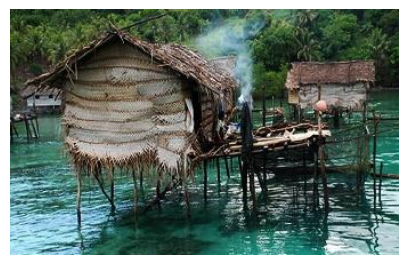

(ii)

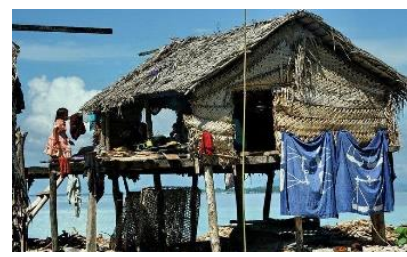

(iii)

Figure 1: Three Variations of Bajau Laut Traditional Houses

(Sources: (i) "Bajau Laut traditional houses on boats" [Photograph] [n.d.]; (ii)

"Bajau Laut traditional houses on water" [Photograph] [n.d.]; (iii) "Bajau Laut traditional houses on land" [Photograph] [n.d.].)

In the context of the Bajau Laut community's traditional house also exists through the process of mass circulation. The history of the Bajau Sea community has 
proven that at first they were housed on boats (Figure 1[i]). On the sociological demands of the Bajau Laut community began building houses on water (Figure 1[ii]) and home on land (Figure 1[iii]). In this study, researchers focus on the Bajau Laut tradition house only

\section{Bajau Laut Houseboat}

The people of Bajau Laut bought many used boats from the Suluk community who live on the islands and coast of Sabah. In the early stages of many craftsmen among the well-known Bajau Laut people made boats. Each component of the boat used by the Bajau Laut community has its function. The boat of Bajau Laut people can be divided into two categories namely the main boat and side boat (biral). There are three main types of boats, namely lepa, lansa, bayanan and tempel. Viral boats and gutters are used to catch fish on the shore.

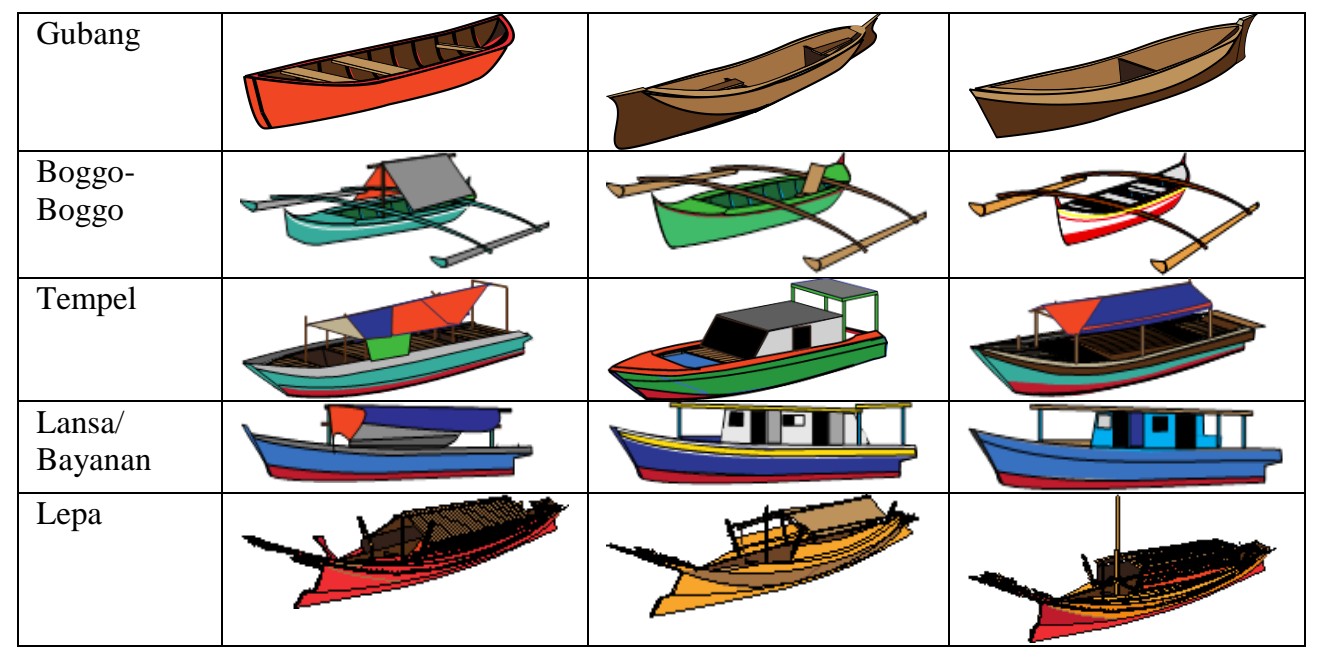

Figure 2: Bajau Laut houseboat variations in Sabah (Source: Zaimie Sahibil [2014].)

\section{Space Design of Bajau Laut Houseboat}

The design of the Bajau Laut boat home is made to know the function of the space parts. The Jesteru section discusses and describes the concepts and functions of space design. The structure can be interpreted as the components of the place to produce a solid frame. The design component of Bajau Laut's boat space based on structure, function and size. Each component is examined in detail by the type of house, i.e. boat house as shown in following diagram: 


\begin{tabular}{|c|c|c|c|}
\hline Bil & Shape & Space & Cultural Interpretation \\
\hline 1. & Bog & $\begin{array}{l}\text { Component of Gubang } \\
\text { - Bulih space } \\
\text { - Tanggah space } \\
\text { - Mundahan space } \\
\\
\text { Component of Boggo- } \\
\text { boggo } \\
\text { - Kibin Bulih space } \\
\text { - Mohang Bulihan space } \\
\text { - Tanggah space } \\
\text { - Mohang Mundahan space } \\
\text { - Kibin Mundahan space }\end{array}$ & $\begin{array}{l}\text { a) As a place to play Bajau Laut } \\
\text { children, if not used as fishing. } \\
\text { b) Gubang becomes a vehicle and } \\
\text { transportation. } \\
\text { a) Place trust rites like } \\
\text { pamatulakan (the place to drive } \\
\text { evil spirits to distract Bajau } \\
\text { Laut people).). } \\
\text { b) Store and transport the corpse } \\
\text { to the land. } \\
\text { c) The new bride's place is } \\
\text { isolating with the main boat. } \\
\text { d) Vehicles to locate fish. } \\
\text { e) Due to the passage of time, the } \\
\text { boat is fitted with a water pump } \\
\text { engine to facilitate movement. }\end{array}$ \\
\hline 3. & Ten & $\begin{array}{l}\text { Component of Ruang } \\
\text { Tempel } \\
\text { - Kibin Bulih space } \\
\text { - Mohang Bulihan space } \\
\text { - Pahalian space } \\
\text { - Patulihan space } \\
\text { - Mohang Mundahan space } \\
\text { - Kibin Mundahan space } \\
\text { Component of Bayanan } \\
\text { - Kibin Bulih space } \\
\text { - Mohang Bulihan space } \\
\text { - Pahalian space } \\
\text { - Patulihan space } \\
\text { - Mohang Mundahan space } \\
\text { - Kibin Mundahan space }\end{array}$ & $\begin{array}{l}\text { a) House boats is where to cook. } \\
\text { b) Storage of fish catches. } \\
\text { c) Place of family activity. } \\
\text { d) Place of birth. } \\
\text { e) Place for wedding. } \\
\text { f) Place for rest, sleeping, eating } \\
\text { and discussions. } \\
\text { g) A place to mortuary case of } \\
\text { death. } \\
\text { h) A place to handle the newborn } \\
\text { baby, the wet custom of the } \\
\text { newborn baby foot into the sea } \\
\text { water. This custom invites sea } \\
\text { spirits to newborns. } \\
\text { i) The place of making a horror } \\
\text { (cold powder) by women of } \\
\text { Bajau Laut society. }\end{array}$ \\
\hline
\end{tabular}




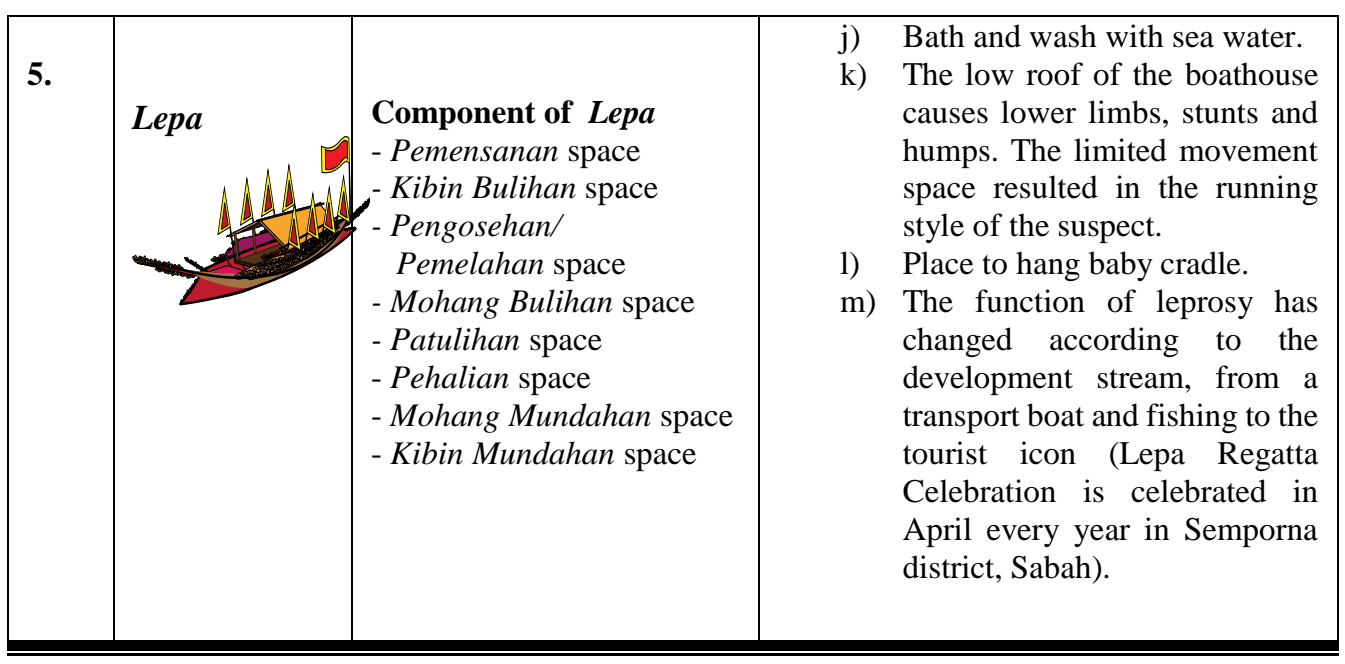

Figure 3: Space component and boat cultural interpretation (Source: Zaimie Sahibil [2014].)

The main component of the main boat space (lepa) is divided into the censorship space, the space of the cibin kibin, the room of dumping / boating, the room of the extravagant room, the resting room, the room of the room, the space of the room and the room of the kibin. Various cultural activities take place in every major boat space component such as customs, culture and beliefs. This activity is a factor affecting the function of the boat space. Environmental factors, cosmology, modernisation, socialisation and evolution of time also affect the filling of the meaning of space in the main boathouse of Bajau Laut society.

Figure 4 , is a side boat or bore used by the Bajau Laut community comprising gubang and boggo-boggo. Overall the design of space components is the same but only distinguished by the size and design of the boat as an example; the design of boggo-boggo has a special advantage as a counterweight. Main boats are sticky, sticky and lepa. The main type of boat is used by the Bajau Laut community as a houseboat. The design of space components is identical only by the size between the three boathouses. The space components contained in the main boat are the censorship, the cibin, the slaughtering/slaughtering, the grunts, the rehabilitation, the chambers of space, the homeowners and the kibin. 


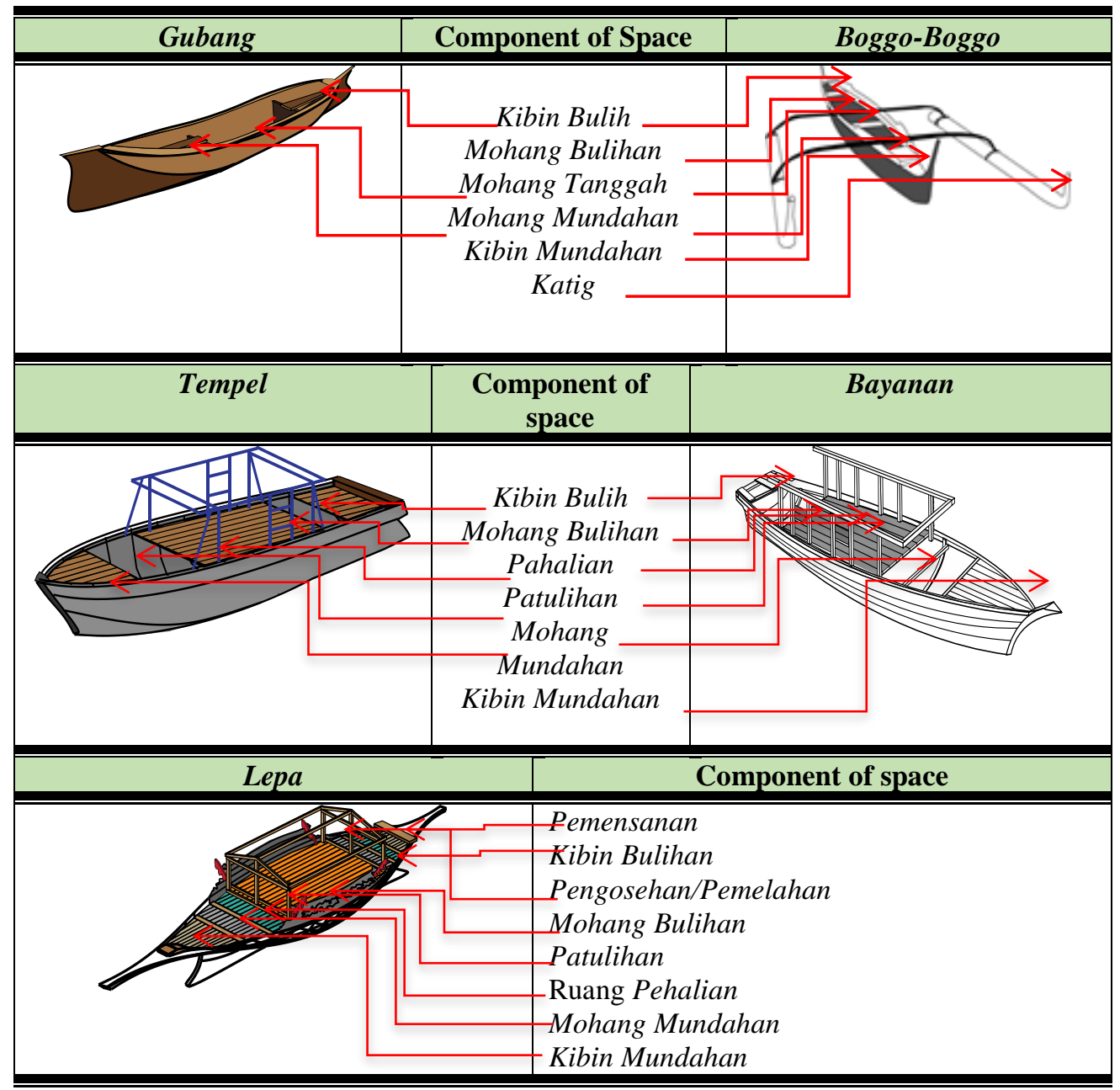

Figure 4: Houseboat component standard space (Source: Zaimie Sahibil [2014].)

Functions between gut, boggo-boggo and paste have a relationship between one and the other. In this context, the Bajau Laut people who can have potholes, boggo-boggo, paste, shell and lepa-lepa. The function chain between the boating house and the main boathouse is as follows:

a. Cocks and bogons serve as a means of transport from the beach, as the main boats cannot go through shallow water.

b. Cubes, boggo-boggo and paste work as a bed, if the main houseboat is not enough.

c. The main boat is not used as a fishing vehicle, but the gecko, boggo-boggo or paste will work because it is easy to operate. 
d. The main boat serves as a space for the practice of traditional and cultural activities such as weddings, births and deaths.

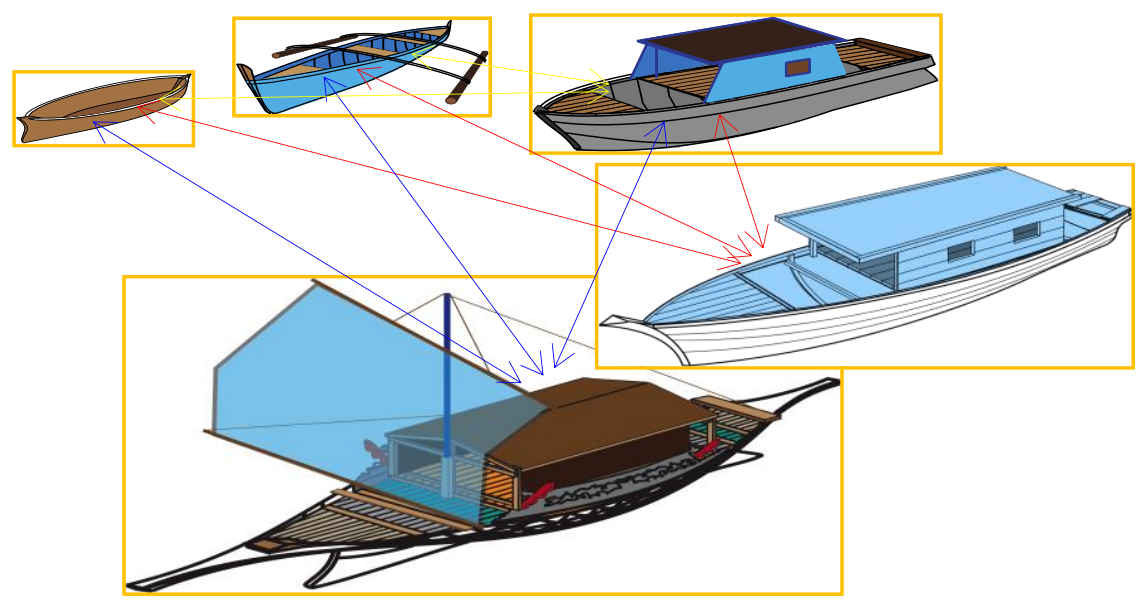

Figure 5: Relation of functional boat house with the main houseboat (Source: Zaimie Sahibil [2014].)

In addition to the main function, the Bajau Laut houseboat is also used in wedding ceremony and death. The Bajau Sea community living in the houseboat is a major factor in the emergence of other functions. In a wedding ceremony, for example, require a large space through a pair of two or three boats. Space in a boat is used for the cinema, space for dancers, musicians, banquets, cooking dishes and more entertaining guests. Although this ceremony occurs once in a while, the function of the boat space is changing according to the current situation. In the death ceremony, the boat function turned into a funeral vehicle by showing the flag symbol as a death note. For example, if the flag is tracked on the front of the boat symbolises the man's body, the opposite is, if the flag is tracked on the rear of the boat symbolises a woman's body.

\begin{tabular}{|l|l|l|}
\hline Main boat house & Description & \multicolumn{1}{|c|}{ Cultural Intepretation } \\
\hline
\end{tabular}




\begin{tabular}{|c|c|l|}
\hline \hline (ii) & & \\
\hline \hline \\
\hline
\end{tabular}

Figure 6: Main houseboat function in marriage custom and death (Source: Zaimie Sahibil [2014].)

\section{Structure of Bajau Laut House over Water}

The construction of the Bajau Laut traditional house over water refers to the structure and design of the space. The home is a place to discuss economic activities, in a closed manner that takes into account the environmental factors. Social relationships between the societies are very important for the formation and division of space according to their function. Its design takes into account some social factors such as home function as a shelter, security, place of raising children and discussing their economic development. The materials used to build the Bajau Laut tradition house over water are the materials of wood found in their surroundings.

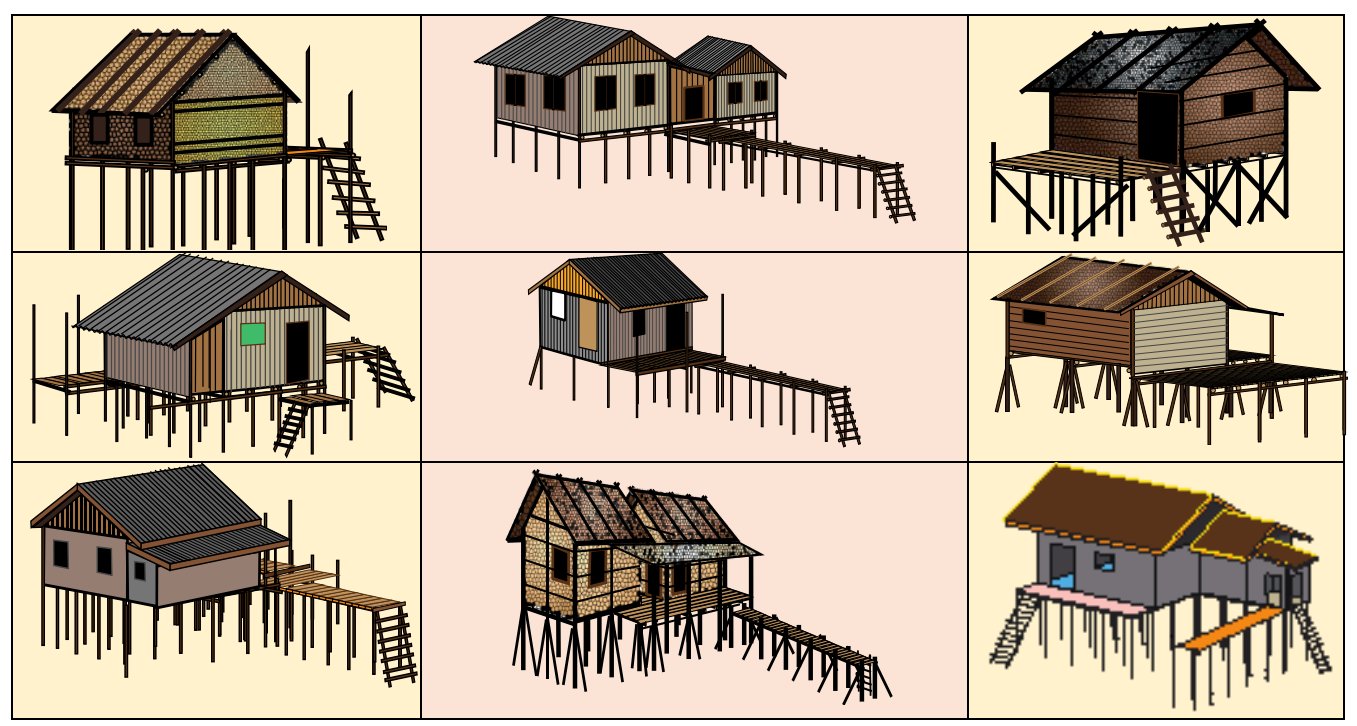

Figure 7: Various Bajau Laut still house (Luma Marilaut)

(Source: Zaimie Sahibil [2014].) 


\section{Analysis Space Design of Bajau Laut Stilt House}

The analysis of the structure of the house design on the Bajau Laut water seeks to determine the function of the part or spaces of the house. The analysis process of space structure design can be divided into several stages as follows:

\begin{tabular}{|c|c|c|}
\hline Bil & $\begin{array}{l}\text { Home Design } \\
\text { Over Water }\end{array}$ & Cultural Interpretation \\
\hline 1. & Space inside house & $\begin{array}{l}\text { a) The main hall conducts traditional, religious and cultural activities. } \\
\text { b) The gathering places discuss things related to souvenirs, customs and } \\
\text { cultures. } \\
\text { c) Place of the marriage ceremony. } \\
\text { d) Places of birth and delivery. } \\
\text { e) Places bathing and cemeteries } \\
\text { f) A place for dead carcases in the event of death. } \\
\text { g) Wedding banquet venue. } \\
\text { h) Council of circumcision girls in the house, the boy in the porch room. } \\
\text { i) Dining place. } \\
\text { j) A place for girl bed. } \\
\text { k) Place of worship. }\end{array}$ \\
\hline 2. & Serambi space & $\begin{array}{l}\text { a) The place to relax. } \\
\text { b) A place for men to carry a basket weaving, repairing nets and net. } \\
\text { c) Beds for boys. } \\
\text { d) This space is known as male space as it is entirely used by men to } \\
\text { relax, accept guests and discuss current matters. } \\
\text { e) Places to hold custom and religious occasions such as marriage and } \\
\text { tahlil. }\end{array}$ \\
\hline 3. & Kusih & $\begin{array}{l}\text { a) A place to cook and store kitchen utensils and groceries. } \\
\text { b) A place for women to provide food. } \\
\text { c) A place for the family to relax meets, chat, have breakfast, eat or relax. } \\
\text { d) Known as a female room, space to celebrate female guests besides for } \\
\text { a place to cook. } \\
\text { e) Place for children, socialise or to prepare for banquets. It is called } \\
\text { space for 'kitchen people'. }\end{array}$ \\
\hline 4. & Pelantar space & $\begin{array}{l}\text { a) A place to waiting rooms waits for men back from catching fish. } \\
\text { b) Place a boat binding (biral) } \\
\text { c) Place for washing and drying clothes. } \\
\text { d) Fish frying room and used as a place to prepare meals for a particular } \\
\text { occasion. } \\
\text { e) Place for drying fish. }\end{array}$ \\
\hline 5. & Jambatan & $\begin{array}{l}\text { a) Lounge, female chat and while making cold powder. } \\
\text { b) Place dried fish on a floor or bridge. } \\
\text { c) Clothing baskets. } \\
\text { d) Head lice activity is also more comfortable at the bridge. }\end{array}$ \\
\hline
\end{tabular}




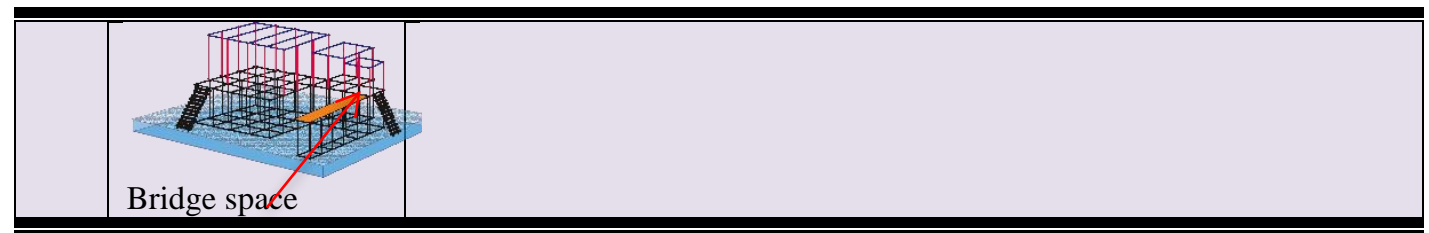

Figure 8: Analysis of space, structure, function and size of Bajau Laut stilt house (Source: Zaimie Sahibil [2014].)

Figure 8 describes the structure of the interior space of the Bajau Sea traditional house over the water. The main hall serves as a general activity room, guests or family celebrations. The lime diagrams (Figure 8[1]) are also used as dining spaces or customs activities. Squared space (Figure 8[2]) serves as a place to relax and store fishing gear. Sometimes this room also functions as a dining room, a rest and a sleeping area. The kitchen space is built to be walled and walled to create the comfort of the occupants (privacy). Place cooking and storing cooking utensils [Figure 8(3)]. In Bajau Laut society, social relations are very concerned about the separation of sex between their children and the outside community. Thus the room serves as a place for women to deal with. This room also functions as a bed. The penthouse space (Figure 8[4]) is constructed of roofed and walled walls to create comfort. This room serves as a place for guests to visit as close relatives, cousins and families. This room is also sometimes used for homeowners as a bedroom and dining room. The bridge (Figure 8[5]) is a building structure that connects the Bajau Laut tradition house with other neighbours. Along the structure of the rope is tied to the clothes drying.

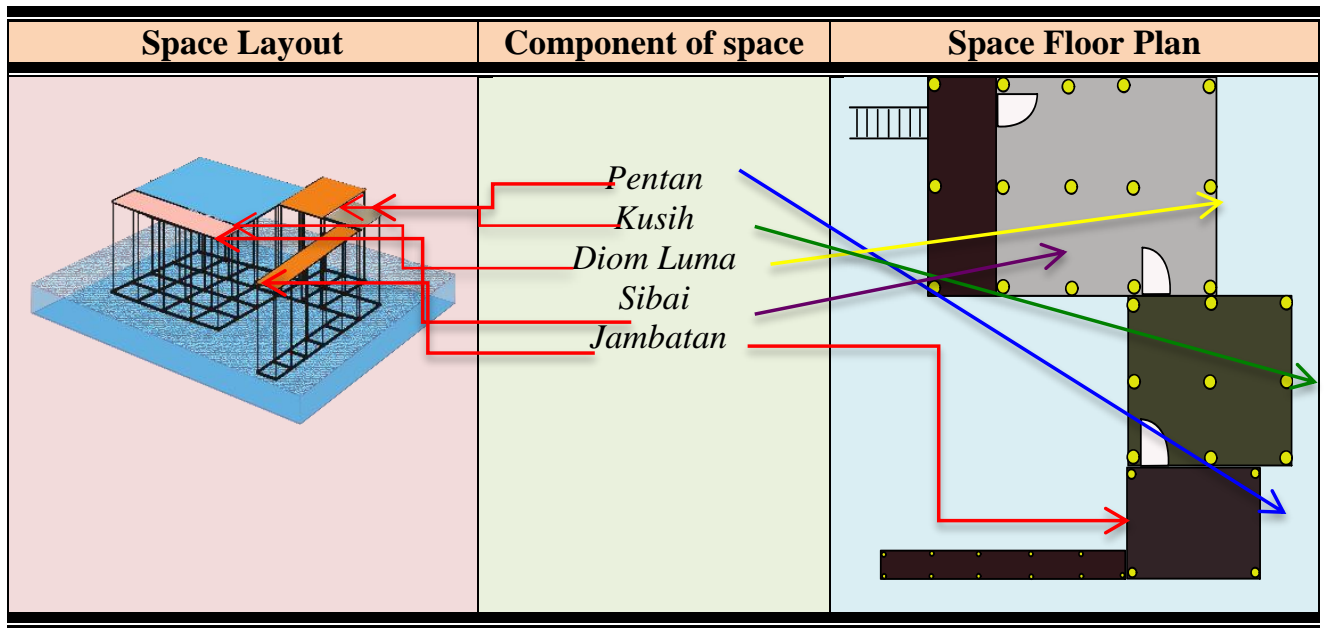

Figure 9: Position of house space components (Source: Zaimie Sahibil [2014].) 


\section{The Bajau Traditional House}

The construction of the Bajau Laut people's traditional home base on the land only takes a short time, within a week. Small built-in homes and simple, easy-to-build designs and without any special plans. The Bajau Laut community also takes into account several factors in the construction of their homes as shelters, security and places for raising children. The number of households living in a house is also usually a family, which is between two and three families. The Bajau Laut community house is built without the middle column on the inside of the house. Open space can create free and comfortable feeling suitable for public use and public places of worship (Zulkifli Hanafi, Azmi Luddin, Nor A'zam Shuib, \& Jamel Ariffin, 2001, p. 58).

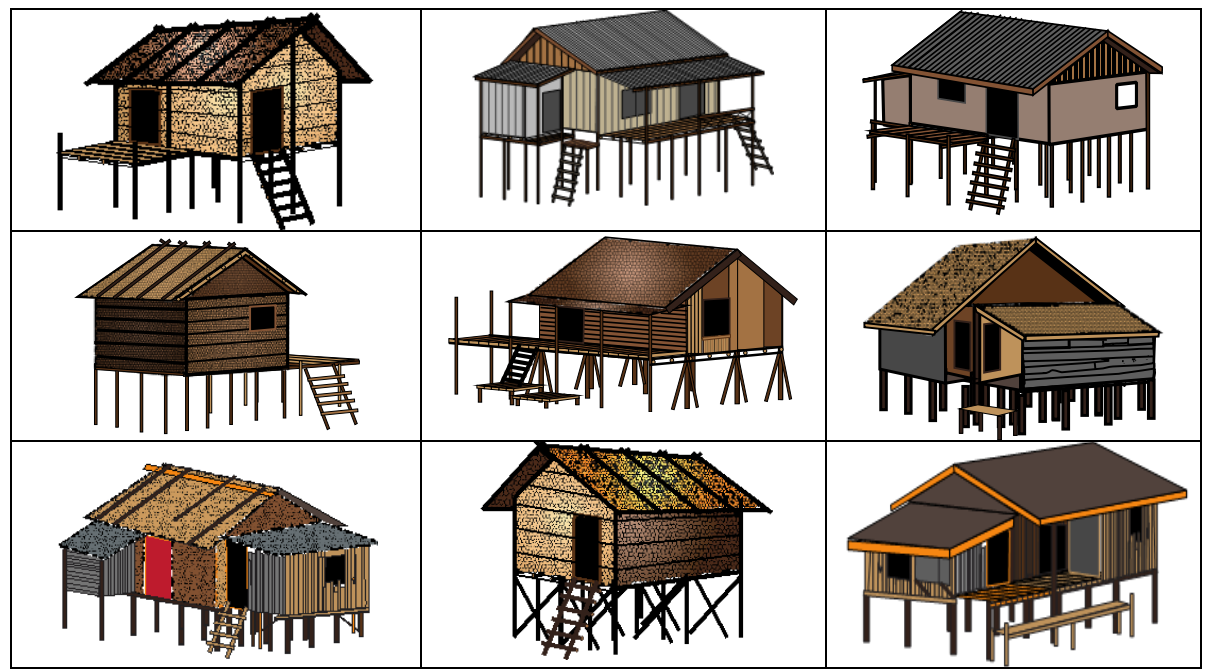

Figure 10: Various Bajau Laut houses (Luma Maraliah)

(Source: Zaimie Sahibil [2014].)

\section{Bajau Laut Traditional House Space Design}

This section is the analysis of the structure of the home-based Bajau Sea space design to determine the function of the space in each section. This section also discusses and describes the concepts and functions of space design. The analysis process of space structure design can be divided into the following stages:

\begin{tabular}{|l|l|l|}
\hline \hline Bil & $\begin{array}{c}\text { Home Design on the } \\
\text { Ground }\end{array}$ & \multicolumn{1}{c|}{ Cultural Interpretation } \\
\hline \hline 1. & Diom Luma & $\begin{array}{c}\text { The Bajau Laut community likes to gather to discuss sustenance, } \\
\text { to regulate the customs and cultural functions. Customary and } \\
\text { cultural activities in space are as follows: - } \\
\text { a) Wedding weddings } \\
\text { b) Death }\end{array}$ \\
\hline \hline
\end{tabular}




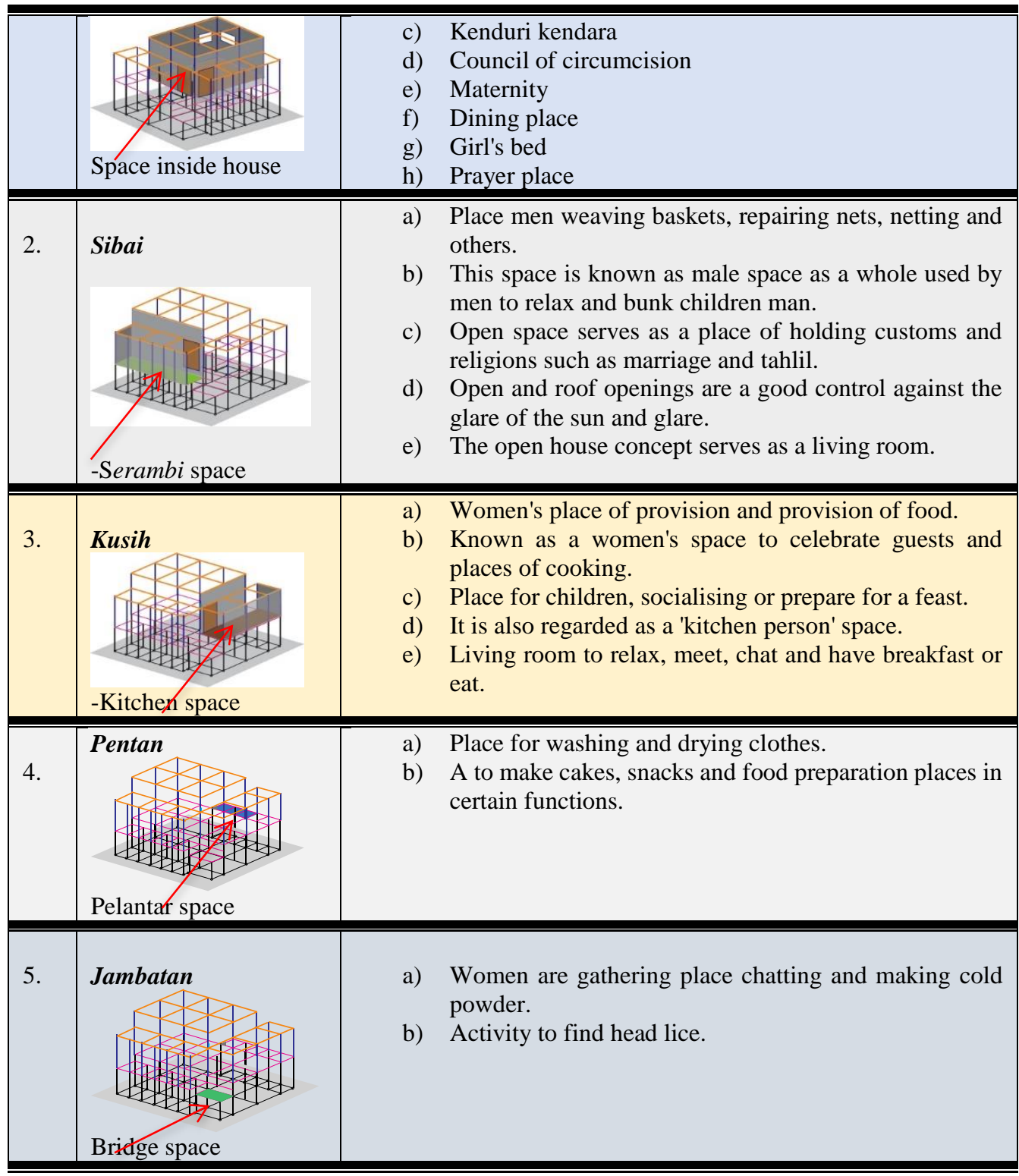

Figure 11: Component Analysis of Space Structure and Cultural Interpretation (Source: Zaimie Sahibil [2014].)

The structure of the luma diuma section is non-porous, the floor is made of slabs and grated slabs and smudges to provide comfort to the occupants. The distance between floors gives a good ventilation system to the occupants. It functions as the main space and is the most widespread in size compared to other spaces. This space is also a bed, dining, dressing and a place to celebrate guests. 
Sibai is designed in size 4 feet wide and long according to the size of the luma diom. Sibai is built with roofed, floored and walled shapes. This space is also known as a family room lounge and as a male chat room. In addition, it also serves as a place to discuss economic activities and to repair nets. Sometimes this space works as a dining room, a rest and a sleeping area.

The cobbler is in line with the building of luma dive, roofed and walled. The buggy space is also built outside or inside the house, depending on the comfort of the occupants. The cobbled space inside the house has a small space, compared to the cobblestone located outside the house. This kusih serves as a cooking space and stores all cooking utensils and groceries. However, there are some Bajau Laut communities that mention the kubih as a field. The meal was in the cobbled room. This meal has no table and chairs. It is only floor-based. Dining serves as a place to dine with family members.

The construction of the pentan is in line with the cobbled, roofed and walled construction. This space serves as a place to celebrate the closest guest, bedroom and dining room. Food washing, crockery and clothing activities are done in this section. The bridge space is a building structure that connects houses with other homes. The bridge also functions as a gateway and entrance, washing and chat room for women

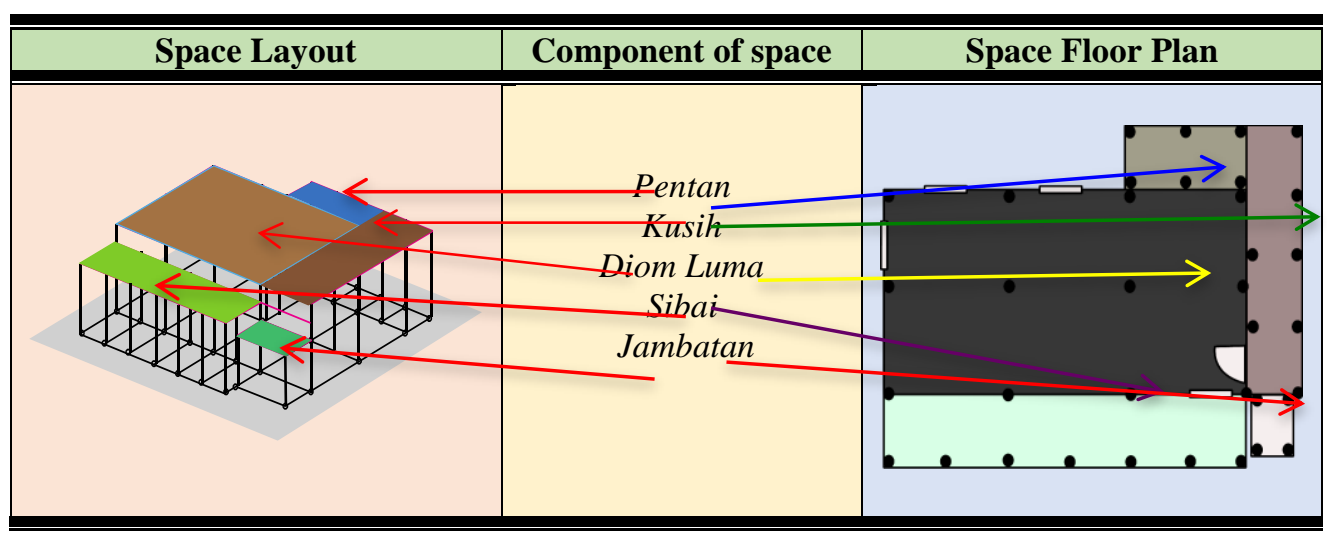

Figure 12: Space component and cultural interpretation (Source: Zaimie Sahibil [2014].)

Bajau Laut's traditional house spaces are generally divided into three parts, the front, middle and back. Figure 12 describes the position of the front room (room and bridges), middle space (luma diuma) and rear space (pentan and kusih).

It is undeniable that people who in the past lived their lives in the oceans in the houseboats. Nowadays, more people live in a stroke home either on the sea or on the mainland. The process of transitioning from sea to land has brought the same implications as the community remains a fisherman, living in a Waterhouse on land and inland. However, people are more likely to stay home in the sea or land, but the 
sea remains the main place to find food sources and survival. Life in the boat is a life full of freedom from the restraint of government regulation. The Jesteru, they are free to travel in the ocean to find a living. The mobility and displacement of the houseboat into the house on the water is due to the convenience factor to sell the catch and to obtain the necessities. For example, it is easy to get food, drinking water and diesel fuel. Home and water are safer as a shelter, especially for the monsoon season. Awareness of children's education has also prompted people to build permanent homes over water and land.

\section{Conclusion}

Home is an essential cultural tool in the life of a society. The Bajau Laut community house and its construction represent a cultural form for the Bajau Laut people who occupy it. Bajau Laut's traditional home is a precious heritage of heritage and has been designed and constructed to show how well the Bajau Laut people are creative and in the use of building materials in their surroundings. The design illustrates the policy in use and craftsmanship according to current requirements, adapting weather and use of building materials.

Several factors influence the style of the Bajau Laut community tradition in Sabah. Home architecture is influenced by the environmental factors, the environment, the way of life and the value. In addition to the environmental factors, Bajau Laut's home architecture is also influenced by the quality of the craftsmanship. It is adapting social and spiritual aspects combined into design harmoniously to create a building that meets the needs of the Bajau Laut community.

Although the concept of home and home design concepts has remained the same and its equality, its function and cultural concept are the same. For example, the space in a houseboat and a permanent home is the same as a bed, resting, eating, managing household matters and organising traditional and cultural activities. There is a significant difference that the main function of the houseboat is to find a living in the sea. On the other hand, the house remains a place of residence and a place to conduct ceremonies as well as raise children

\section{Acknowledgements}

The author is grateful to the following research assistants who assisted during the research:

Aliff Che Brahim (25 years old), Visual Arts Technology student, Universiti Malaysia Sabah (UMS).

Andry Chin (26 years old), Kampung Bambangan, Tamparuli, Sabah.

Iziq Ismail (27 years old), Ph.D. candidate in Architecture, Universiti Teknologi Malaysia (UTM). 
Ku Ahmad Kuzairie Ku Mohammad (26 years old), Visual Arts Technology student, Universiti Malaysia Sabah (UMS).

Mohd Farit Azamuddin (24 years old), Visual Arts Technology student, Universiti Malaysia Sabah (UMS).

Muslim Mattajim (36 years old), Visual Arts Technology student, Universiti Malaysia Sabah (UMS).

Nor Asmidayu Mohammad Fauzi (24 years old), Visual Arts Technology student, Universiti Malaysia Sabah (UMS).

Nursuziani Zahari (24 years old), Visual Arts Technology student, Universiti Malaysia Sabah (UMS).

Suryana Hamzah (24 years old), Visual Arts Technology student, Universiti Malaysia Sabah (UMS).

\section{References}

Bajau Laut traditional houses on boats [Photograph]. (n.d.). Retrieved from https://scontent-hkg3-2.xx.fbcdn.net/v/t31.0-

8/17097585_235976293531641_4716887239970497731_o.jpg?nc_cat=110\&_nc_h $\mathrm{t}=$ scontent-hkg3-

2.xx\&oh=b84e80205327aa039e7b5b7e3f61acd9\&oe=5D031CF9

Bajau Laut traditional houses on land [Photograph]. (n.d.). Retrieved from https://4.bp.blogspot.com/ChyzJP9NuMk/WODJ1rPMvhI/AAAAAAAAWM A/brbi4yeJHDYbv-PKRxz6Mf_nWXY

TIueACLcB/s1600/images\%2B\%25286\%2529.jpg

Bajau Laut traditional houses on water [Photograph]. (n.d.). Retrieved from http://2.bp.blogspot.com/_XLOpi2JEQmo/SwaGOhM3bPI/AAAAAAAABFw/b8D RgWxsF10/s400/Semporna+Unik.jpg

Sopher. (1965). The Sea Nomads: A Study of the Maritime Boat People of Southeast Asia. Singapore: National Museum Singapore.

Zaimie Sahibil. (2014). Konsep Dan Reka Bentuk Ruang Rumah Tradisi Bajau Laut Di Sabah. Ph.D. thesis, Faculty of Humanities, Arts and Heritage, Universiti Malaysia Sabah, Kota Kinabalu, Malaysia.

Zulkifli Hanafi, Azmi Luddin, Nor A'zam Shuib, \& Jamel Ariffin. (2001). Teori dan Prinsip Reka Bentuk. Kulim: Amber-Salora Publication 